\title{
Preparing For The Profession: The Accounting Job Search And Beyond
}

Ellen L. Landgraf, Loyola University Chicago, USA

Brian B. Stanko, Loyola University Chicago, USA

Darcia Jinkerson, Loyola University Chicago, USA

\begin{abstract}
This paper provides a detailed description of a unique program focused on preparing students for entry into the accounting profession. The program, Preparing for the Profession, consisted of four distinct workshops provided to accounting majors during fall semester 2010. Planning for the program began a year earlier during a meeting of Accounting Advisory Board members and faculty. Each session addressed a distinct aspect of the accounting profession and consisted of a panel discussion of six to eight accounting and business professionals. The sessions were 90 minutes in length and discussion focused on 25 pre-submitted questions by student attendees. Specific objectives were formulated for each session and assessment data subsequent to the workshop's completion indicated that the program was a success in meeting those objectives.
\end{abstract}

Keywords: Accounting Education; Accounting Profession; Job Search; Careers Accounting

\section{INTRODUCTION}

e $\mathrm{n}$ the midst of numerous financial scandals during the past decade, the accounting profession has been closely monitored and exceptionally scrutinized. Regulatory laws have changed and an influential public debate exists on how investors can be better protected. Similarly, within the accounting industry, an increasing number of academics and professionals have begun to scrutinize recent accounting graduates. How can accountants be trusted to accurately report international companies' financials and auditors be relied upon to uncover large-scale fraud if graduates are not adequately prepared for the profession? Critics of this new generation of accounting professionals cite several specific concerns, including a sense of entitlement, a lack of motivation and work ethic, and unrealistic expectations of firm life (Vance and Stephans, 2010).

Although many students graduate with good technical skills, they often lack sufficient soft skills and motivation necessary to succeed in the profession. Further, accounting majors seem to believe that communication skills are not as essential when the accounting profession is compared to other so-called professions (Ameen, Bruns, and Jackson, 2010). Traditional classroom settings focus on technical skills, but fail to highlight the importance of other skills in the workplace. In addition, Kavanagh and Drennen found in a 2007 study that students have a different perspective than employers on what skills are most valuable in the profession. Both groups identify similar skills, such as analytical/problem-solving skills, communication skills, and teamwork, as important, but students and employers rank the order of those skills differently. The expectation gap between students and employers has caused various professionals and academics to propose solutions. These recommendations include introducing courses that develop important soft skills and a requirement for accounting majors to reflect on the demands of the profession as a central part of their coursework (Vance and Stephans, 2010; Wilkerson 2010).

A number of accounting departments acted on these recommendations and have implemented extracurricular programs to more adequately prepare accounting students for the workforce. One university created a oneday "boot camp" for juniors and honors program participants (Myring, Wrege and Alst, 2008; Green and Nagle, 2009). Loyola University Chicago, on the other hand, chose to create a workshop-style program. The seminar series titled "Preparing for the Profession" consisted of four different workshops focusing on varying aspects of the accounting industry, specifically public accounting, non-public accounting, the recruiting process and "you", and 
professional certifications. Loyola's accounting department hoped that the workshop series would help students better understand the professional choices that await them, improve their success during the annual recruiting season, see the importance of professional certification, and ultimately be better prepared for firm life. The workshops were presented on Wednesday afternoons during the fall semester 2010 in two-week intervals. Each session was open to all students, including MSA students. Attendance was not required. Despite the fact that attendance was not mandatory, a reasonable number of students attended the workshops. In total, 68 students attended the first workshop session, followed by 43, 38, and 34, respectively. All of the workshops consisted of panel responses to the various questions developed in advance of the workshop. Often, all panel members would respond to the same question as the responses could certainly vary among the panel participants. Time for additional questions was available at the close of each presentation.

\section{THE PREPARING FOR THE PROFESSION PROGRAM IN DETAIL}

For the academic year 2010-11, one of the Department of Accounting and Business Law's initiatives was to offer a fall semester workshop series for accounting majors. The workshop series had been discussed and approved by both the department and the Accounting Advisory Board. The four sessions, each devoted to improving student understanding of the accounting profession and themselves, are described below, along with their specific outcomes:

\section{Session 1: Understanding the Profession - Public Accounting}

Outcome: Students will learn about the public accounting profession from successful Loyola accounting alumni. Work experiences, tasks to be encountered, mentoring, specialization, ongoing professional development, work hours, workload, and work/life balance will be discussed.

The nine panelists that participated consisted of both alums and non-alums that held the position of partner, director or manager in public accounting firms ranging from regional to Big 4. The pre-submitted student questions are included in Appendix A.

\section{Session 2: Understanding the Profession - Non Public Accounting}

Outcome: Students will learn about corporate accounting and reporting, internal audit, government, non-profit, financial services, etc.

The seven panelists that participated were all alumnae of Loyola and held positions such as Analyst, Audit Director, Manager (Corporate Audit), CFO, VP (Wealth Management), Controller and Manager of Compliance. Both for-profit companies (i.e., CNA, Goldman Sachs) and not-for-profit (Northwestern University) entities were represented. The pre-submitted student questions are included in Appendix A.

\section{Session 3: "You" and the Recruiting Process}

Outcome: Students will learn about researching a firm, the interview day, professional follow-up, day 1 anticipation (what to expect), etc. Dining etiquette, social skills, business attire and other topics will also be discussed.

The six panelists that participated included individuals involved in student recruitment from three of the "Big 4" firms and one other accounting firm, as well as Loyola University representatives from Catering Services and Career Management Services. The pre-submitted student questions are included in Appendix A.

\section{Session 4: Professional Certifications}

Outcome: Students will gain an understanding of the many professional certifications in the field of accounting.

The four panelists that participated included two representatives from Becker Professional Education, one of which held a CPA, CFP and CFA, a Risk Manager from one of the "Big 4" firms, and a CFE from a regional forensic accounting firm. 
Each individual/panelist would introduce themselves and then respond to questions from the student audience. The questions were forwarded to the panelists in advance. All questions were general in nature and were designed to help students understand what lies ahead and to recognize that the panelists, now successful accounting professionals, were once like them.

\section{ASSESSMENT OF THE PREPARING FOR THE PROFESSION PROGRAM}

Although anecdotally the program seemed successful, the accounting department was interested in learning more about the students' and panelists' perspectives of the series to help improve future workshops. In the spring semester of 2011, Loyola's accounting department designed a survey to acquire such feedback. A copy of the survey instrument is included in Appendix B. In particular, the Department was interested in learning if the students felt better prepared to enter the profession, had a clearer understanding of the type of accounting work that would coincide with their career aspirations, if the workshop changed their perspective on the accounting profession, and ultimately, if students found the workshops to be generally useful.

Specifically 68 students and 12 panelists replied to the survey. Since students may have attended multiple sessions, the response rate was indeterminate. None of the panelists from the third session responded to the survey, and the overall response rate for panelists for all sessions was $47 \%$. Table 1 provides additional information on the participants of the workshop series.

Table 1: Workshop Participant Students \& Panelists

\begin{tabular}{|l|c|c|c|}
\hline \multicolumn{3}{|c|}{ Students } \\
\hline \multicolumn{1}{|c|}{ Year in School } & \% of Students (n=52) & \multicolumn{1}{c|}{ Session } & \% of Students Attending \\
\hline Freshman & $3.85 \%$ & 1-Public Accounting & $47 \%$ \\
\hline Sophomore & $9.62 \%$ & 2-Non-public Accounting & $47 \%$ \\
\hline Junior & $34.62 \%$ & 3-You and the Recruiting Process & $28 \%$ \\
\hline Senior & $23.08 \%$ & 4-Professional Certifications & Panelists \\
\hline Graduate Student & $28.85 \%$ & \% of Panelists (n=12) \\
\hline \multicolumn{3}{|c|}{$8.3 \%$} \\
\hline Years of Experience & \multicolumn{3}{|c|}{$25 \%$} \\
\hline Less than 5 & \multicolumn{3}{|c|}{$66.7 \%$} \\
\hline 5-9 Years & \multicolumn{3}{|c|}{} \\
\hline 10 or more years & \multicolumn{3}{|c|}{}
\end{tabular}

Table 2 summarizes the respective rankings by session by participants.

Table 2: Participant Rankings of Individual Sessions

\begin{tabular}{|c|c|c|c|c|c|}
\hline $\begin{array}{l}\text { Session 1-Public } \\
\text { Accounting }\end{array}$ & $\begin{array}{c}\text { Students' } \\
\text { Rating } \\
(\mathbf{n}=21)\end{array}$ & $\begin{array}{c}\text { Panelists' } \\
\text { Rating } \\
(\mathrm{n}=2)\end{array}$ & $\begin{array}{c}\text { Session 2-Non-public } \\
\text { Accounting }\end{array}$ & $\begin{array}{c}\text { Students' } \\
\text { Rating } \\
(\mathbf{n}=\mathbf{2 6})\end{array}$ & $\begin{array}{c}\text { Panelists' } \\
\text { Rating } \\
(n=6)\end{array}$ \\
\hline Excellent & $60.0 \%$ & $50.0 \%$ & Excellent & $34.6 \%$ & $50.0 \%$ \\
\hline Good & $31.5 \%$ & $50.0 \%$ & Good & $50.0 \%$ & $50.0 \%$ \\
\hline \multirow[t]{2}{*}{ Average } & $8.5 \%$ & & Average & $15.4 \%$ & \\
\hline & $100 \%$ & $100 \%$ & & $100 \%$ & $100 \%$ \\
\hline $\begin{array}{l}\text { Session 3-You and the } \\
\text { Recruiting Process }\end{array}$ & $\begin{array}{c}\text { Students' } \\
\text { Rating } \\
(\mathbf{n}=\mathbf{2 5})\end{array}$ & $\begin{array}{c}\text { Panelists' } \\
\text { Rating } \\
(\mathbf{n}=\mathbf{0})\end{array}$ & $\begin{array}{c}\text { Session 4-Professional } \\
\text { Certifications }\end{array}$ & $\begin{array}{c}\text { Students' } \\
\text { Rating } \\
(\mathbf{n}=17)\end{array}$ & $\begin{array}{c}\text { Panelists' } \\
\text { Rating } \\
(n=2)\end{array}$ \\
\hline Excellent & $24.0 \%$ & & Excellent & $35.3 \%$ & $100.0 \%$ \\
\hline Good & $64.0 \%$ & & Good & $52.9 \%$ & \\
\hline Average & $4.0 \%$ & & Average & $11.8 \%$ & \\
\hline \multirow[t]{2}{*}{ Below Average } & $8.0 \%$ & & & & \\
\hline & $100 \%$ & & & $100 \%$ & $100 \%$ \\
\hline
\end{tabular}

As noted, both students and panelists, on average, had an overall positive impression of the "Preparing for the Profession" series. In fact, $85 \%$ of all students believed the sessions to be excellent or good. Responding panelists also indicated an above average level of satisfaction with the workshop. Table 3 summarizes student and panelist reactions to a series of statements regarding the sessions. 
Table 3: Participant Responses Regarding Aspects of the Sessions

\begin{tabular}{|c|c|c|c|c|c|c|}
\hline \multicolumn{7}{|c|}{ Student Responses } \\
\hline Statement & $\begin{array}{l}\text { Strongly } \\
\text { Agree }\end{array}$ & $\begin{array}{c}\text { Moderately } \\
\text { Agree }\end{array}$ & Neutral & $\begin{array}{c}\text { Moderately } \\
\text { Disagree }\end{array}$ & $\begin{array}{l}\text { Strongly } \\
\text { Disagree }\end{array}$ & $\begin{array}{c}\text { Unable } \\
\text { to Judge }\end{array}$ \\
\hline $\begin{array}{l}\text { The time of day for each workshop was } \\
\text { convenient to my schedule }(n=44)\end{array}$ & $43.2 \%$ & $40.9 \%$ & $11.4 \%$ & $2.3 \%$ & $2.2 \%$ & \\
\hline $\begin{array}{l}\text { The 2-week interval between workshops was } \\
\text { appropriate }(n=37)\end{array}$ & $48.7 \%$ & $40.5 \%$ & $10.8 \%$ & & & \\
\hline $\begin{array}{l}\text { The workshop series was an efficient use of } \\
\text { your time }(n=37)\end{array}$ & $40.5 \%$ & $46.0 \%$ & $10.8 \%$ & $2.7 \%$ & & \\
\hline $\begin{array}{l}\text { The use of pre-developed questions added value } \\
\text { to the workshop }(n=37)\end{array}$ & $62.2 \%$ & $27.0 \%$ & $8.1 \%$ & $2.7 \%$ & & \\
\hline $\begin{array}{l}\text { The environment was comfortable and } \\
\text { professional for this type of event }(n=44)\end{array}$ & $75.0 \%$ & $18.0 \%$ & $4.5 \%$ & $2.5 \%$ & & \\
\hline $\begin{array}{l}\text { The audience was engaged in the discussion } \\
(\mathrm{n}=44)\end{array}$ & $47.7 \%$ & $43.2 \%$ & $6.8 \%$ & $2.3 \%$ & & \\
\hline Statement & $\begin{array}{l}\text { Strongly } \\
\text { Agree }\end{array}$ & $\begin{array}{c}\text { Moderately } \\
\text { Agree }\end{array}$ & Neutral & $\begin{array}{l}\text { Moderately } \\
\text { Disagree }\end{array}$ & $\begin{array}{l}\text { Strongly } \\
\text { Disagree }\end{array}$ & $\begin{array}{l}\text { Unable } \\
\text { to Judge }\end{array}$ \\
\hline $\begin{array}{l}\text { The panelists answered the questions in a non- } \\
\text { condescending and professional manner }(n=37)\end{array}$ & $75.7 \%$ & $24.3 \%$ & & & & \\
\hline $\begin{array}{l}\text { The panelist responses were clear and easy to } \\
\text { understand }(\mathrm{n}=37)\end{array}$ & $62.2 \%$ & $32.4 \%$ & $5.4 \%$ & & & \\
\hline $\begin{array}{l}\text { The panelists Jesuit education stood out where } \\
\text { relevant }(\mathrm{n}=37)\end{array}$ & $29.7 \%$ & $27.1 \%$ & $32.4 \%$ & $5.4 \%$ & & $5.4 \%$ \\
\hline $\begin{array}{l}\text { The panelists were sincere in their participation } \\
(\mathrm{n}=37)\end{array}$ & $56.8 \%$ & $32.4 \%$ & $8.1 \%$ & $2.7 \%$ & & \\
\hline $\begin{array}{l}\text { The panelist comments were useful toward my } \\
\text { professional development }(n=37)\end{array}$ & $56.8 \%$ & $40.5 \%$ & $2.7 \%$ & & & \\
\hline $\begin{array}{l}\text { The group of panelists interacted well together } \\
(\mathrm{n}=37)\end{array}$ & $48.7 \%$ & $37.8 \%$ & $10.8 \%$ & $2.7 \%$ & & \\
\hline $\begin{array}{l}\text { The panelists were accessible when the } \\
\text { workshop reached its close }(n=37)\end{array}$ & $40.6 \%$ & $40.5 \%$ & $13.5 \%$ & & $2.7 \%$ & $2.7 \%$ \\
\hline
\end{tabular}

\begin{tabular}{|c|c|c|c|c|c|c|}
\hline \multicolumn{7}{|c|}{ Panelist Responses } \\
\hline Statement & $\begin{array}{l}\text { Strongly } \\
\text { Agree }\end{array}$ & $\begin{array}{l}\text { Moderately } \\
\text { Agree }\end{array}$ & Neutral & $\begin{array}{l}\text { Moderately } \\
\text { Disagree }\end{array}$ & $\begin{array}{l}\text { Strongly } \\
\text { Disagree }\end{array}$ & $\begin{array}{l}\text { Unable } \\
\text { to Judge }\end{array}$ \\
\hline $\begin{array}{l}\text { The time of day for each workshop was } \\
\text { convenient to my schedule }(n=12)\end{array}$ & $41.7 \%$ & $50.0 \%$ & & $8.3 \%$ & & \\
\hline $\begin{array}{l}\text { The use of pre-developed questions added value } \\
\text { to the workshop }(n=12)\end{array}$ & $58.3 \%$ & $33.4 \%$ & & & & $8.3 \%$ \\
\hline $\begin{array}{l}\text { The environment was comfortable and } \\
\text { professional for this type of event }(n=12)\end{array}$ & $83.3 \%$ & $16.7 \%$ & & & & \\
\hline $\begin{array}{l}\text { The audience was engaged in the discussion } \\
(n=12)\end{array}$ & $66.7 \%$ & $33.3 \%$ & & & & \\
\hline $\begin{array}{l}\text { The students will be better able to assess what } \\
\text { type of work in the accounting industry will } \\
\text { best fit their goals and skill set as a result of the } \\
\text { workshop series }(n=12)\end{array}$ & $50 \%$ & $41.7 \%$ & $8.3 \%$ & & & \\
\hline $\begin{array}{l}\text { The students will be better prepared to begin a } \\
\text { job or internship search after attending the } \\
\text { workshop series }(n=12)\end{array}$ & $50 \%$ & $41.7 \%$ & $8.3 \%$ & & & \\
\hline $\begin{array}{l}\text { The workshops gave an accurate representation } \\
\text { of what working in public accounting/non- } \\
\text { public accounting is like }(n=12)\end{array}$ & $50 \%$ & $25 \%$ & $25 \%$ & & & \\
\hline $\begin{array}{l}\text { Students are, in general, well-prepared to enter } \\
\text { the accounting profession }(n=12)\end{array}$ & $33.3 \%$ & $41.7 \%$ & $16.7 \%$ & $8.3 \%$ & & \\
\hline
\end{tabular}

As noted, the survey indicates that $85 \%$ of student participants felt considerably more prepared to enter the accounting industry after participating in the workshop sessions. However, the survey also indicates that room for improvement exists in increasing the student-panelist interaction, increasing participation, and providing relevant information to students at all grade levels. 


\section{DISCUSSION AND SUMMARY}

Students who attended the "Preparing for the Profession" series cited that the workshops were a positive experience and that it improved their knowledge and preparedness in a variety of areas. Specifically, $91.7 \%$ of students rated the sessions as Excellent or Good. In addition, $84.2 \%$ of students rated the workshops as an efficient use of their time. Although a positive student impression is important, it is more crucial to determine if the sessions had the desired impact to inform and prepare them to enter the accounting industry. All the students surveyed cited that they felt better prepared to work in accounting after attending the series, but $36.84 \%$ of these students reported only a moderate effect. Some specific student comments related to the question include:

The workshop series reinforced my understanding of the profession. By attending the workshops, I was reminded of what I should know (e.g., preparing for the CPA test, interviewing, etc.), things that a graduate should already be well aware of. For under classmen, I would suspect these workshops were incredibly valuable, at least they should have been.

The workshops gave me a deeper understanding of the accounting profession and what to expect when pursuing a career after graduation.

\section{Ifound clarity to some concerns.}

All of the responding student participants agreed that the series helped them to better understand what area of accounting would best fit their goals, with $78.95 \%$ reporting that it helped "a great deal" or "considerably." Similarly, all respondents cited that the panelists' comments were useful to their professional development. These statistics illustrate that the workshops had a positive impact on student participants and that program goals were achieved. However, the open-ended comments, as they relate to several questions, suggested areas for improvement.

Overall, the students enjoyed the workshop presentations and found them relevant. However, $78.95 \%$ stated that it did not change their perspective of the accounting industry. This would indicate that either these students already had a fairly accurate picture of the industry or the workshops did not provide enough information to make a difference. Open-ended comments also highlight some areas of program improvement. These centered on suggestions for more student-panelist interaction and more information pertinent to graduate students. For example, one student responded "increase student engagement and provide students with more opportunities to network with the professionals", while another wrote "have presentations focused specifically on graduate students". These comments suggest that improved student-panelist interaction, during the panel discussion or afterwards, would help students form a more realistic expectation of the workplace. Furthermore, this suggestion would be easy to implement by simply expanding the workshop session by 30 minutes. The suggestion pertaining to graduate students is slightly more problematic. The workshops are open to accounting majors from freshman through graduate students, so the students will unavoidably come with different levels of background knowledge about the accounting industry. These workshops were geared toward juniors and giving them an accurate representation of the profession. Therefore, it was important not to assume too much prior knowledge to help all attendees leave with a clear understanding. However, time for more student-professional interactions could give time for graduate students to ask professionals more advanced questions on their own time. Both problems are relatively slight and can be minimized in future workshops. As 2010 was the first year for the workshop series, it is not surprising that students have some useful suggestions for improvement.

Overall, Loyola's "Preparing for the Profession" workshop series helped students better understand the accounting profession and enabled them to identify areas that would best meet their goals. Workshop assessment results address some of the critic's aforementioned concerns pertaining to recent accounting graduates. The program makes accounting majors' expectations of firm life more realistic by sharing with them professional opinions of their predecessors. In addition, if students accurately understand the demands of the profession, they are more likely to develop the soft skills that employers emphasize. They could also become more motivated once they recognize the effort and performance that is necessary to succeed. An open dialogue between students and professionals can slowly narrow the expectation gap between the two groups, leaving both new graduates and employers more 
satisfied in the long run. Most importantly, it introduces students to information about the workplace that is simply not present in traditional lecture-based courses. The workshop series can help accounting majors become more prepared to enter the workplace on a student-by-student basis. Although workshops sponsored by one university will not stop the concerns about recent accounting graduates, similar programs on a wide scale can certainly improve the quality of new accounting professionals in the future.

\section{AUTHOR INFORMATION}

Ellen L. Landgraf holds a Ph.D. from the University of Illinois at Chicago, an MBA from Northern Illinois University and a BBA from Loyola University Chicago. She is a registered Certified Public Accountant (Illinois.) Dr. Landgraf's work experience includes positions at the IRS and in public accounting (both Big Eight and small practitioner) prior to her over thirty years in academia. Her research interests are in the areas of executive compensation, corporate governance and social responsibility, corporate disclosure and reputation and ethics and accounting. E-mail: elandgr@luc.edu

Brian B. Stanko holds a Ph.D. from the University of Kentucky, and an MBA and a BS from Eastern Illinois University. He is a registered Certified Public Accountant (Illinois.) Dr. Stanko's work experience includes five years in accounting and financial reporting and twenty years in academia. His research interests are in the areas of cash flow analysis, annual report analysis, corporate reporting and accounting education. He currently serves as the Chair of the Accounting and Business Law Department at Loyola University Chicago. E-mail: bstanko@luc.edu (Corresponding author)

Darcia Jinkerson is a recent graduate of Loyola University Chicago with a BBA summa cum laude in accounting. As of early 2012, she is working as a tax intern in Private Company Services at Deloitte Tax, LLP. Prior to her current position, she completed a tax internship at the Chicago office of the tax firm WTAS, LLC. She was involved in various extra-curricular organizations as a student of Loyola University Chicago, including Women in Business, Beta Alpha Psi and Alpha Sigma Nu. From 2010-2011, she was the President of Women in Business. E-mail: djinkerson@luc.edu

\section{REFERENCES}

1. Ameen, Elsie, Sharon M. Bruns, and Cynthia Jackson. "Communication Skills and Accounting: Do Perceptions Match Reality?” The CPA Journal. July 2010. 63-65. Web. 4 Feb 2011.

2. Green, Sharon L. and Brian M. Nagle. "Implementing a Accounting Honors Program: One School's Response to the Changing Landscape of Accounting Education." The Journal of Learning in Higher Education 5.2 (2009): 23-32. Web. 4 Feb 2011.

3. Kavanagh, Marie H., and Lyndal Drennen. "What skills and attributes does an accounting graduate need? Evidence from student perceptions and employer expectations." Accounting and Finance 48 (2008): 279300. Web. 10 Apr 2011.

4. Myring, Mark, William Wrege and Lucinda Van Alst. "Accounting Boot Camp for College Juniors." College Teaching Methods and Styles Journal 4.3 (2008): 13-22. Web. 4 Feb 2011.

5. Vance, Carol A. and William L. Stephans. "How Does the New Generation of Accounting Majors Measure Up?" The CPA Journal. November 2010. 6-8. Web. 4 Feb 2011.

6. Wilkerson, Jack E. Jr. "Accounting Educators as the Accounting Profession's Trustees: Lessons from a Study of Peer Professions.” Issues in Accounting Education 25.1 (2010): 1-13. Web. 4 Feb 2011. 


\section{APPENDIX A - SESSION QUESTIONS}

\section{Session I: Understanding the Profession - Public Accounting}

Discussion Questions (to be asked of panelists by students)

1. When you came to Loyola, did you come to study accounting? Or did you change majors during your academic career?

2. As a graduate of Loyola, would you share with us one of your favorite memories? This does not necessarily have to be accounting related or it can be.

3. Would you share with the group some of your interview memories (good/bad), some questions that you were asked (if you recall), and your sense of nervousness on the interview day?

4. Why did you choose accounting as your career path and would you do it again?

5. As a Loyola graduate, do you feel that you were (i) as well prepared (ii ) better prepared or (iii) less well prepared, for the professional challenges you encountered, as graduates of other universities?

6. Would you discuss some interesting challenges that you have faced along the way?

7. How have you prepared yourself over the years for working with people (within/outside the firm) and the various personalities that you encounter?

8. What do you personally look for in your support staff?

9. Would you share with us some profession/industry insight? Changes that you are encountering, new areas of focus?

10. What are your typical work days like (i.e., \# of hours worked, \% of time doing planning/research versus interacting with other staff or clients)?

11. What are the skills you most utilize or most need to improve to get promoted (e.g., public speaking, written communication, computer software)?

12. What expectations are there by your firm to get an advanced degree? Does the firm provide tuition reimbursement for a graduate degree?

13. How much out-of-town travel do you encounter throughout the year?

14. What are the key pros/cons of public accounting v. industry v. government?

15. What are some of the personal characteristics that you feel lead to success in public accounting?

16. How can you tell if the profession is the right choice for you?

17. What do you like most about this profession; and what do you dislike?

18. If I start out in public accounting, have I limited my other career options?

19. What are your thoughts on acquiring a Jesuit education? Do you see a connection between the core curriculum, Jesuit values and the profession?

20. Given the dynamic elements of the profession and its constant changes, how do we prepare ourselves to be creative life-long learners?

21. How does the accounting profession serve society, or as they say, the common good?

22. Given what you expected going into the profession, was it what you found?

23. Who do you believe is ultimately responsible for career management?

24. Can you share with us some of your first day/first week experiences with your first employer?

25. What are some of the most important reading materials or sources you use on a daily basis?

\section{Session 2: Understanding the Profession - Non-public Accounting}

Discussion Questions (to be asked of panelists by students)

1. When you came to Loyola, did you come to study accounting? Or did you change majors during your academic career?

2. As a graduate of Loyola, would you share with us one of your favorite memories? This does not necessarily have to be accounting related or it can be.

3. Would you share with the group some of your interview memories (good/bad), some questions that you were asked (if you recall), and your sense of nervousness on the interview day? 
4. Why did you choose accounting as your career path and would you do it again?

5. Would you discuss some interesting challenges that you have faced along the way?

6. How have you prepared yourself over the years for working with people (within/outside the firm) and the various personalities that you encounter?

7. What do you personally look for in your support staff?

8. Would you share with us some profession/industry insight? Changes that you are encountering, new areas of focus?

9. What are your typical work days like (i.e., \# of hours worked, \% of time doing planning/research versus interacting with other staff or clients)?

10. What are the skills you most utilize or most need to improve to get promoted (e.g., public speaking, written communication, computer software)?

11. What expectations are there by your company to acquire an advanced degree?

12. How much out-of-town travel do you encounter throughout the year?

13. What are the key pros/cons of industry v. public accounting v. government?

14. What are some of the personal characteristics that you feel lead to success in the non public accounting sector?

15. How can you tell if the profession is the right choice for you?

16. What do you like most about your profession; and what do you dislike?

17. If I start out in non public accounting, have I limited my other career options?

18. What are your thoughts on acquiring a Jesuit education? Do you see a connection between the core curriculum, Jesuit values and the profession?

19. Given the dynamic elements of the profession and its constant change, how do we prepare ourselves to be creative life-long learners?

20. How does the accounting profession serve society, or as they say, the common good?

21. Given what you expected going into the profession, was it what you found?

22. Can you share with us some of your first day/first week experiences with your first employer?

23. What are some of the most important reading materials or sources you use on a daily basis?

\section{Session 3: "You" and the Recruiting Process}

\section{Discussion Questions - Firm Recruiters}

1. "When you're in an interview and you are asked a question that you are pretty sure you do not know the answer to, how do you suggest responding? Should you give the best answer or simply say you know I think I might have an idea of what the right answer is but I am not sure, etc."

2. "What is one thing that one can do to really stand out amongst his/her peers?"

3. What are some of the biggest mistakes students make on their resumes?

4. If I am applying for a specific job should I include an objective on my resume?

5. What are some of common mistakes students make when they interview?

6. How important is personal appearance, grooming, etc. when you interview?

7. To what degree should students personalize their resumes for jobs?

8. What is a normal turnaround time for a thank you letter?

9. Is it appropriate to ask an interviewer questions regarding why they selected a given employer?

10. How long should a college resume be in length? And how descriptive should your position descriptions be if you have work experience.

11. Should references be provided on the resume or provided after the fact?

12. Do your firms conduct background checks on students before they are hired?

13. How involved are all of you and your firms in the social media scene?

14. When you begin a position with the firm, what will your first few days/weeks entail?

15. Would you share with the group some great or not so great interview memories, some questions that you were asked (if you recall), and student sense of nervousness on the interview day?

16. Why did you choose accounting as your profession and would you do it again? 
17. How have you prepared yourself over the years for working with people (within/outside the firm) and the various personalities that you encounter?

18. What are the skills you most utilize or most need to improve to get promoted (e.g., public speaking, written communication, computer software)?

19. What expectations are there by your firm to get an advanced degree? Does the firm provide tuition reimbursement for a graduate degree?

20. What are some of the personal characteristics that you feel lead to success in public accounting?

\section{Discussion Questions - CMS-Related}

1. How soon should I prepare a resume and have it reviewed by SBA Career Management Services?

2. If I have applied for a position through SBA Careers Online that is part of the on-campus interview schedule, how will I be notified that I have been selected for an interview?

3. What are three mistakes students make in preparing for their interview?

4. In what ways can SBA Career Management Services help me to enhance my networking skills and understand how to make the most out of career fairs and employer events?

5. Is it too early to connect with SBA Career Management Services as a freshman or sophomore?

6. Will I find more opportunities on SBA Careers Online? Rambler link? Should business students use both?

7. The day of my on-campus interview, how can I most effectively engage with members of that firm who act as greeters before I start my interview? 


\section{APPENDIX B - SURVEY INSTRUMENT}

\section{"Preparing for the Profession" Workshop Series Survey}

Thank you for participating in the 2010 "Preparing for the Profession" Workshop Series this past fall term. In order to improve future workshops, the ABL Department is hoping that you would take a moment to complete this questionnaire. To begin, please find the appropriate section, student or panelist, and answer a few questions about your experience.

Session 1 - Public Accounting

Session 2 - Non public Accounting

Session 3 - You and the Recruiting Process

Session 4 - Professional Certifications

Consider this scale when answering the questions: $\quad 1=$ very much disagree

$2=$ disagree

$3=$ neutral

$4=$ agree

$5=$ very much agree

\section{Students}

1. The time of day for each workshop was convenient to my schedule?

2. The 2-week interval between workshops was appropriate?

3. The workshop series was an efficient use of your time?

4. The use of pre-developed questions added value to the workshop?

5. The environment was comfortable and professional for this type of event?

6. The audience was engaged in the discussion?

7. The panelists answered the questions in a non-condescending and professional manner?

8. The panelist responses were clear and easy to understand?

9. The panelists Jesuit education stood out where relevant?

10. The panelists were sincere in their participation?

11. The panelist comments were useful toward my professional development?

12. The group of panelists interacted well together?

13. The panelists were accessible when the workshop reached its close?

14. The seminar changed my perspective on the accounting industry? If so, how?

15. The workshop series has helped me to be better prepared to work in the accounting profession? If so, how?

16. The workshop series provided a clearer picture of the type of accounting work that would best fit my goals? If so, how?

17. The quality of the workshop(s) attended was high?

18. How many workshops did you personally attend? 1234

19. If you attended more than one workshop, which workshop was your favorite? 1234

20. Year in school? 12345 


\section{Panelist}

1. The time of day for the workshop sessions was convenient to my schedule?

2. The use of pre-developed questions assisted me in preparing for the workshop?

3. The environment was comfortable and professional for this type of event?

4. The audience was engaged in the discussion?

5. The students will be better able to assess what type of work in the accounting industry will best fit their goals and skill set as a result of the workshop series?

6. The students will be better prepared to begin a job or internship search after attending the workshop series?

7. The workshops gave an accurate representation of what working in public accounting/non-public accounting is like?

8. Students are, in general, well-prepared to enter the accounting profession?

9. The quality of the workshop session was high?

10. Are there improvements that you would suggest for next year's event? If so, what might some be?

11. Years of experience in the accounting field? Less than 5 years, 5-9 years, 10 or more

12. What workshop did you participate in? 1234

Thank you for your participation! 


\section{NOTES}

